\title{
Cotylenin A and arsenic trioxide cooperatively suppress cell proliferation and cell invasion activity in human breast cancer cells
}

\author{
TAKASHI KASUKABE ${ }^{1,2}$, JUNKO OKABE-KADO ${ }^{2}$, NOBUO KATO ${ }^{3}$, \\ YOSHIO HONMA $^{4}$ and SHUNICHI KUMAKURA ${ }^{1}$ \\ ${ }^{1}$ Department of Medical Education and Research, Faculty of Medicine, Shimane University, \\ Izumo 693-8501; ${ }^{2}$ Research Institute for Clinical Oncology, Saitama Cancer Center, Saitama 362-0806; \\ ${ }^{3}$ Institute of Scientific and Industrial Research, Osaka University, Osaka 567-0047; \\ ${ }^{4}$ Cancer Center, Faculty of Medicine, Shimane University, Izumo 693-8501, Japan
}

Received September 22, 2014; Accepted November 4, 2014

DOI: 10.3892/ijo.2014.2760

\begin{abstract}
Arsenic trioxide (ATO) is an approved treatment for acute promyelocytic leukemia (APL). It has also shown potential for treatment of multiple myeloma and various solid tumors including breast cancer. The requirement of high, toxic concentrations for the induction of apoptosis in non-APL and solid tumor cells is a major limitation for its use in other hematological malignancies and solid tumors. We have examined whether inducers of differentiation of leukemia cells can control the growth of solid tumor cells. In the present study, we found that cotylenin A, a plant growth regulator and a potent inducer of differentiation in myeloid leukemia cells, significantly potentiated both ATO-induced inhibition of cell growth in a liquid culture, and ATO-induced inhibition of anchorageindependent growth in a semi-solid culture in human breast cancer MCF-7 and MDA-MB-231 cells. ISIR-005 (a synthetic cotylenin A-derivative) was also able to enhance ATO-induced growth inhibition. The combined treatment with cotylenin A and ATO induced cleaved caspase-7 in MCF-7 cells at the concentrations which ATO alone scarcely induced and cotylenin A alone only weakly induced. Expression of survivin in MCF-7 cells was markedly decreased with the presence of both cotylenin A and ATO, although the expression of survivin was only slightly decreased by cotylenin A or ATO alone. The pretreatment with $\mathrm{N}$-acetylcysteine significantly reduced the combination treatment-induced cell growth inhibition. These data suggest that induction of cleaved caspase-7, inhibition of survivin and oxidative responses are important events in the corporative inhibition in the growth of MCF-7 cells induced
\end{abstract}

Correspondence to: Professor Takashi Kasukabe, Department of Medical Education and Research, Faculty of Medicine, Shimane University, Izumo 693-8501, Japan

E-mail: kasukabe@med.shimane-u.ac.jp

Key words: cotylenin A, arsenic trioxide, proliferation, invasion activity, breast cancer cells by both cotylenin A and ATO. Furthermore, we found that the combined treatment with cotylenin A and ATO also could be effective in suppressing the invasive capacity of MDA-MB-231 cells determined with the impedance-based xCELLigence Real-Time Cell Analysis technology. These results suggest that cotylenin A is an attractive enhancer for the ATO-induced anticancer activities in human breast cancer.

\section{Introduction}

Breast cancer is the most common cancer among women with a relatively high incidence of $20 \%$ of all malignancies and remains one of the leading causes of cancer-related death worldwide (1). Although chemotherapy has improved outcomes for patients, the marginal benefits achieved with cytotoxic agents seem to have reached a plateau $(2,3)$. Recently, preventive agents and targeted therapies directed at the estrogen receptor, progesterone receptor, and human epidermal growth factor 2 receptor have resulted in improved clinical outcomes for many women with breast cancer (3). However, further challenges remain in treating tumors that do not express these molecular targets or tumor cells that become resistant for these molecular targets. Therefore, the development of new therapeutic agents or new combination therapy for these clinically intractable tumors is still highly desirable.

Arsenic trioxide (ATO) is an approved treatment for acute promyelocytic leukemia (APL). ATO induces differentiation at lower concentrations and induces apoptosis at higher concentrations in APL cells (4). It is now well established that ATO induces complete remission in $80-90 \%$ of newly diagnosed patients with APL, as well as in $60-90 \%$ of all-trans retinoic acid refractory patients (5-7). Furthermore, the anticancer activity of ATO was also intensively studied in various other hematological malignancies and several solid tumors, including breast cancer (8-13). Although ATO is very effective in the treatment of APL, ATO has been less successful in other malignancies at tolerable doses. The doses of ATO required to exert detectable anticancer effects in solid tumors are much higher than those required to inhibit hematological malignan- 

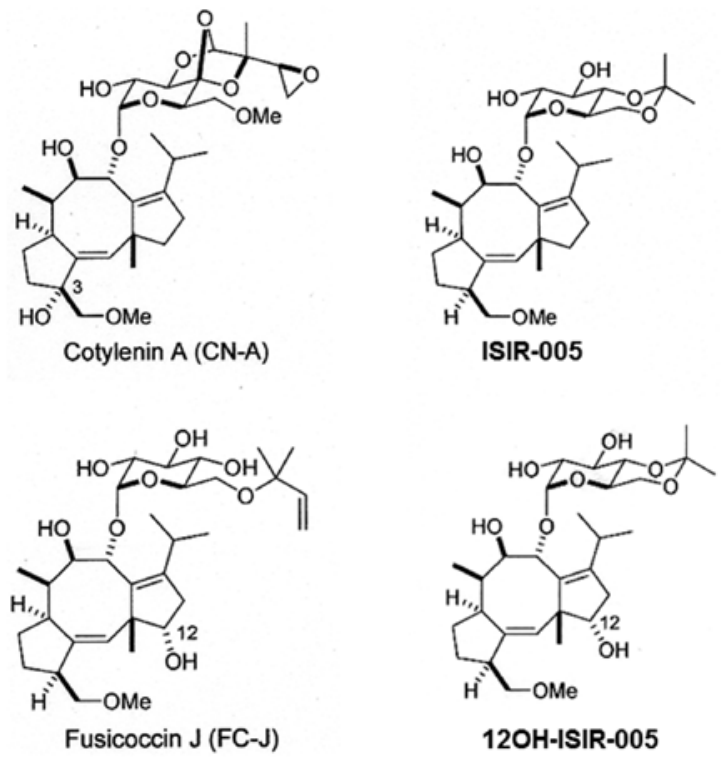

Figure 1. Structures of cotylenin A (CN-A) and CN-A analogues.

cies (14-16). Combination therapy is a frequently used method in clinical practice to improve the therapeutic effect and reduce the toxicity of anticancer drugs $(17,18)$. Therefore, new strategies are essential to enhance the efficacy of ATO, while reducing its dose in order to avoid severe side-effects.

We have examined whether inducers of differentiation in leukemia cells can control the growth of solid tumors. Cotylenin A (CN-A), which is a fucicoccan-diterpene glycoside with a complex sugar moiety, was originally isolated as a plant growth regulator and has been shown to affect several physiological processes in higher plants (19). We previously reported that $\mathrm{CN}$-A has a potent differentiation-inducing activity in several human and murine myeloid leukemia cell lines and in leukemia cells that were freshly isolated from patients with acute myeloid leukemia (20-23). We previously found that treatment with $\mathrm{CN}-\mathrm{A}$ plus rapamycin, which also has a potent differentiation-inducing activity in myeloid leukemia cells (24), effectively inhibited the proliferation of human breast cancer cell line MCF-7 cells $(13,25,26)$. In the present study, we found that a new combination treatment with $\mathrm{CN}-\mathrm{A}$ and low doses of ATO showed marked anti-proliferative and anti-metastatic effects in human breast cancer cells.

\section{Materials and methods}

Cell culture. Human breast cancer cell lines (MCF-7, MDA-MB-231 and T47D) and human promyelocytic leukemia cell line HL-60 cultured in RPMI-1640 supplemented with $10 \%$ fetal bovine serum (FBS) at $37^{\circ} \mathrm{C}$ in a humidified atmosphere of $5 \%$ carbon dioxide in air.

Materials. ATO, nitroblue tetrazolium (NBT), 12-O-tetradecanoylphorbol-13-acetate (TPA) and N-acetyl-L-cysteine (NAC) were purchased from Sigma-Aldrich (St. Louis, MO, USA). CN-A, ISIR-005, 12OH-ISIR-005 and Fusicoccin J (FC-J) were prepared as previously described $(19,27)$. The structures of CN-A, ISIR-005, 12OH-ISIR-005 and FC-J are shown in Fig. 1. YM155 was obtained from Selleckchem (Houston,
TX, USA). Methyl cellulose was purchased from Wako Pure Chemical Industries (Osaka, Japan). Human apoptosis array kit and anti-p27 antibody were obtained from R\&D Systems (Minneapolis, MN, USA). Anti-caspase-7, anti-survivin, anti-p21 and anti-XIAP antibodies were purchased from Cell Signaling Technology (Danvers, MA, USA). Anti- $\alpha$-tubulin antibody was obtained from Santa Cruz Biotechnology (Santa Cruz, CA, USA).

Assay of cell differentiation for leukemia cells. NBT reduction was assayed colorimetrically as previously described (28). Briefly, HL-60 cells were incubated in $1 \mathrm{ml}$ of serum-free medium containing $1 \mathrm{mg} / \mathrm{ml} \mathrm{NBT}$ and $100 \mathrm{ng} / \mathrm{ml}$ TPA at $37^{\circ} \mathrm{C}$ for $30 \mathrm{~min}$. The reaction was stopped by adding $\mathrm{HCl}$. Formazan deposites were solubilized in DMSO, and the absorption of the formazan solution at $560 \mathrm{~nm}$ was measured in a spectrophotometer.

Assay of cell growth. Cells were seeded at $1-3 \times 10^{4}$ cells $/ \mathrm{ml}$ in a 24-well multidish. After culture with or without test compounds for the indicated times, viable cells were examined by a modified MTT (3-(4,5-dimethylthiazol-2yl)-2,5-diphenyltetrazolium bromide) assay as previously reported (25).

Assay of anchorage-independent growth. MCF-7 cells $\left(2 \times 10^{3}\right.$ cells/well) and MDA-MB-231 cells $\left(4 \times 10^{3}\right.$ cells/well) were plated in RPMI-1640 supplemented with $10 \%$ fetal bovine serum and $1.0 \%$ methylcellulose in a 24-well ultra-low attachment multidish (Corning Inc., Corning, NY, USA). Colonies containing 10 or more cells were counted 12 days after seeding.

Western blot analysis. Cells were packed after washing with cold PBS and then lysed at a concentration of $1 \times 10^{7}$ cells $/ \mathrm{ml}$ in lysis buffer CelLytic ${ }^{\text {TM }}$ M (Sigma-Aldrich) supplemented with a proteinase inhibitor cocktail and phosphatase inhibitor cocktail 1/2 (Sigma-Aldrich). Equal amounts of protein were separated on 5-20\% SDS-polyacrylamide gels (Wako Pure Chemical Industries). Proteins were electrophoresed on gels and transferred to an Immobilon-P membrane (Millipore, Bedford, MA, USA) using the primary antibodies. An antirabbit or anti-mouse IgG HRP-linked antibody (Cell Signaling Technology) was used as a secondary antibody (1:2,000 dilution). Bands were identified by treatment with Immune-Star ${ }^{\mathrm{TM}}$ HRP chemiluminescence (Bio-Rad Laboratories, Hercules, CA, USA) for $5 \mathrm{~min}$ at room temperature and detected using a Fuji Lumino Image Analyser LAS-4000 system (Fuji Film Co., Ltd., Tokyo, Japan) (28). All western blots shown are representative of at least 3 independent experiments.

Apoptosis array. Cells were plated in $100-\mathrm{mm}$ plastic dishes at a density of $4 \times 10^{4}$ cells $/ \mathrm{ml}$ and incubated with $\mathrm{CN}-\mathrm{A}$ $(3.5 \mu \mathrm{g} / \mathrm{ml})$ and ATO $(4 \mu \mathrm{M})$ at $37^{\circ} \mathrm{C}$ for $96 \mathrm{~h}$. The cells were washed with PBS twice and solubilized at $1 \times 10^{7}$ cells $/ \mathrm{ml}$ in lysis buffer (Human Apoptosis Array kit). The lysates were resuspended and rocked gently at $2-8^{\circ} \mathrm{C}$ for $30 \mathrm{~min}$. After centrifuging, the supernatant was transferred into a clean tube. Then, $400 \mu \mathrm{g}$ of total protein was used for the Human Apoptosis Array kit according to the manufacturer's protocol as previously described (29). 


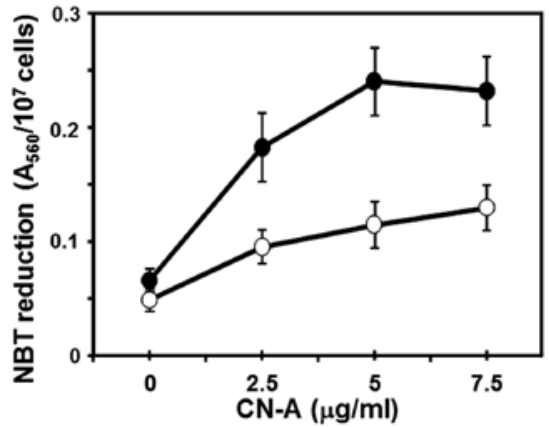

Figure 2. Induction of NBT reduction of human promyelocytic leukemia HL-60 by the treatment with CN-A and ATO. HL-60 cells $\left(1 \times 10^{5}\right.$ cells $\left./ \mathrm{ml}\right)$ were cultured with $\mathrm{CN}-\mathrm{A}$ in the presence (closed circle) and absence (open circle) of $0.25 \mu \mathrm{M}$ ATO for 4 days. Then, NBT reducing activities were determined. Values are expressed as mean \pm standard deviation of three determinations.

In vitro cell invasion assay. Cell invasion activity was measured by real-time monitoring of cell invasion using xCELLigence Real-Time Cell Analyzer (Roche-Diagnostics Japan, Tokyo, Japan). For continuous monitoring of cell invasion $5 \times 10^{4}$ cells were seeded in a 5\% (v/v) Matrigel-coated CIM-Plate 16 with $10 \%$ serum serving as the chemoattractant in the lower chamber according to the manufacturer's protocol.

\section{Results}

$C N-A$ sensitizes ATO-induced growth inhibition of human breast cancer MCF-7 and MDA-MB-231 cells. We and others have reported that $\mathrm{CN}-\mathrm{A}$ and ATO (at low doses) alone could induce the differentiation of human myeloid leukemia cells $(4,21)$. Firstly, we found that $\mathrm{CN}-\mathrm{A}$ and $0.25 \mu \mathrm{M}$ ATO synergistically induced the NBT reduction (one of typical differentiation markers of human leukemia cells) (Fig. 2). Then we examined whether these combined treatment also could be effective in the suppression of the proliferation of solid tumor cells including breast cancer cells. CN-A and ATO synergistically inhibited the proliferation of human breast cancer cell line MCF-7 cells (Fig. 3A). Although ATO alone even at a higher concentration $(6 \mu \mathrm{M})$ inhibited the growth of MCF-7 cells to $\sim 50 \%$ of control and CN-A $(1.25 \mu \mathrm{g} / \mathrm{ml})$ alone slightly inhibited the growth of MCF-7 cells, in the presence of CN-A $(1.25 \mu \mathrm{g} / \mathrm{ml})$ ATO at $1.5-4 \mu \mathrm{M}$, which is in or close to the range of clinically achievable concentrations $(30,31)$, could inhibit the growth of MCF-7 cells to $<50 \%$ of control (Fig. 3A). Unexpectedly, MDA-MB-231 cells were more sensitive to ATO: at $1 \mu \mathrm{M}$ ATO alone could inhibit the proliferation of MDA-MB-231 cells to $<50 \%$ of control (Fig. 3B). CN-A also effectively enhanced the ATO-induced growth inhibition of MDA-MB-231 cells (Fig. 3B).

$C N-A$ and ATO synergistically inhibit anchorage-independent growth of MCF-7 and MDA-MB-231 cells. Since anchorageindependent growth is well correlated with tumorigenic potential, we next examined whether this combined treatment with CN-A and ATO could effectively inhibit the anchorageindependent growth of these breast cancer cells. Although ATO $(1 \mu \mathrm{M})$ or CN-A $(1 \mu \mathrm{g} / \mathrm{ml})$ alone inhibited colony formation of MCF-7 cells to $\sim 67$ or $64 \%$ of controls, respectively, combined
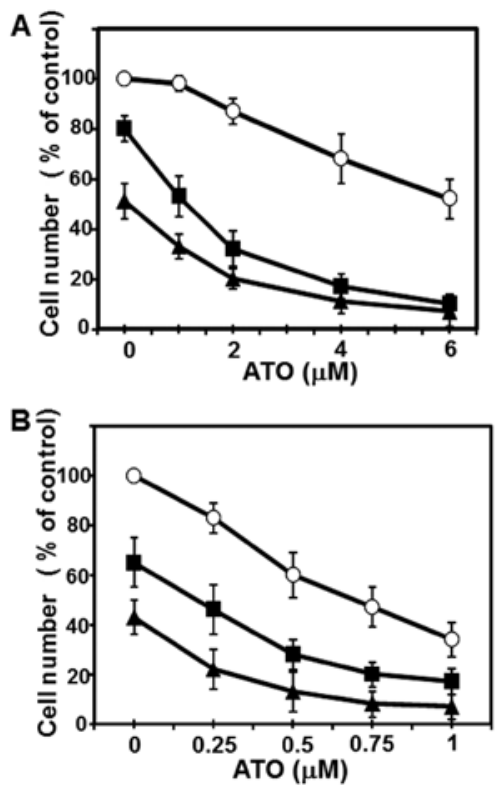

Figure 3. CN-A enhances ATO-induced growth inhibition in MCF-7 cells and MDA-MB-231 cells. (A) MCF-7 cells $\left(1 \times 10^{4}\right.$ cells $\left./ \mathrm{ml}\right)$ were cultured with ATO in the absence (open circle) or presence of $1.25 \mu \mathrm{g} / \mathrm{ml}$ (closed square) and $2.5 \mu \mathrm{g} / \mathrm{ml}$ (closed triangle) CN-A for 5 days. (B) MDA-MB-231 cells $\left(1 \times 10^{4}\right.$ cells $\left./ \mathrm{ml}\right)$ were cultured with ATO in the absence (open circle) or presence of $2.5 \mu \mathrm{g} / \mathrm{ml}$ (closed square) and $5 \mu \mathrm{g} / \mathrm{ml}$ (closed triangle) CN-A for 5 days. Then cell number were determined by the MTT assay. Values are expressed as mean \pm standard deviation of three determinations.
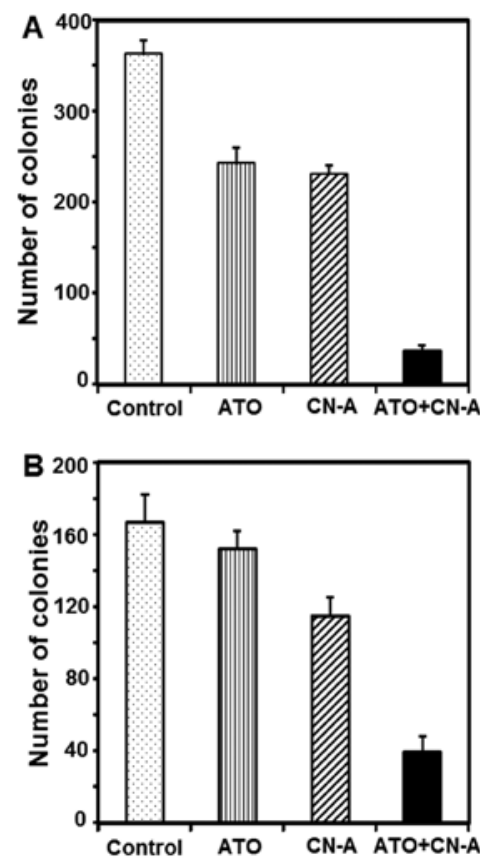

Figure 4. CN-A and ATO synergistically inhibited the anchorage-independent growth of MCF-7 cells and MDA-MB-231 cells. (A) MCF-7 cells $\left(2 \times 10^{3}\right.$ cells/well) and (B) MDA-MB-231 cells $\left(4 \times 10^{3}\right.$ cells/ well) were cultured with (A) $1 \mu \mathrm{g} / \mathrm{ml}$ or (B) $2.5 \mu \mathrm{g} / \mathrm{ml} \mathrm{CN-A}$ in the presence and absence of (A) $1 \mu \mathrm{M}$ or (B) $0.2 \mu \mathrm{M}$ ATO in RPMI-1640 supplemented with $10 \%$ fetal bovine serum and $1.0 \%$ methylcellulose in a 24-well ultra-low attachment multidish. Colonies containing 10 or more cells were counted 12 days after seeding. Values are expressed as mean \pm standard deviation of three determinations.

treatment with ATO and CN-A inhibited colony formation to $10 \%$ of controls (Fig. 4A). Although ATO $(0.2 \mu \mathrm{M})$ alone 

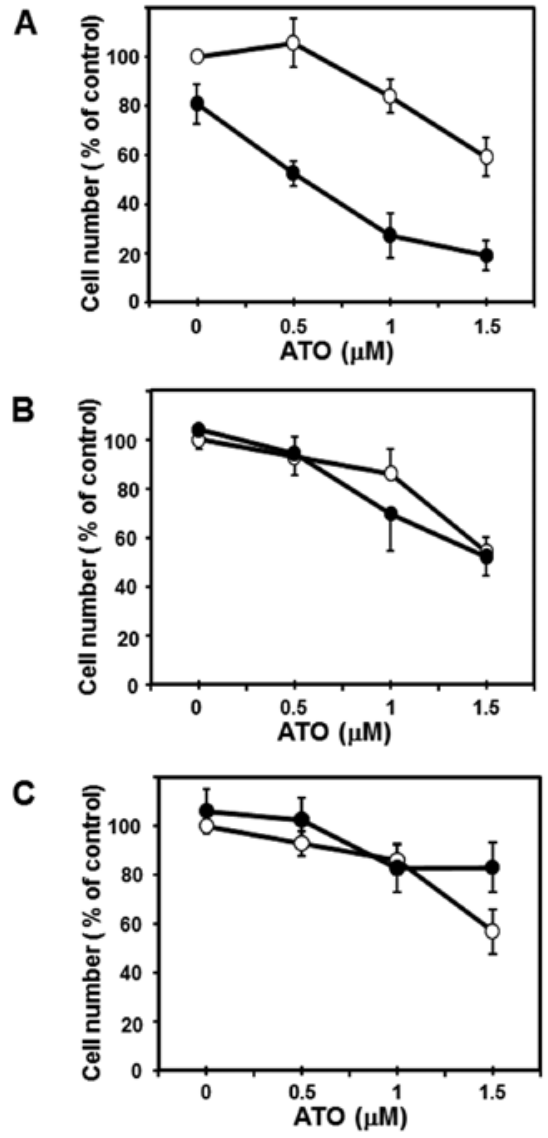

Figure 5. Effects of CN-A analogues on the growth of MCF-7 cells in the presence of ATO. MCF-7 cells $\left(1 \times 10^{4}\right.$ cells $\left./ \mathrm{ml}\right)$ were cultured with ATO in the presence (closed circle) or absence (open circle) of (A) $6 \mu \mathrm{g} / \mathrm{ml} \mathrm{ISIR-005,} \mathrm{(B)}$ $6 \mu \mathrm{g} / \mathrm{ml} \mathrm{FC-J} \mathrm{or} \mathrm{(C)} 6 \mu \mathrm{g} / \mathrm{ml} 12 \mathrm{OH}-I S I R-005$ for 5 days. Then cell numbers were determined by the MTT assay. Values are expressed as mean \pm standard deviation of three determinations.

slightly inhibited colony formation of MDA-MB-231 cells ( $<10 \%$ inhibition) and CN-A $(2.5 \mu \mathrm{g} / \mathrm{ml})$ alone inhibited colony formation of MDA-MB-231 cells to $\sim 69 \%$ of controls, combined treatment with ATO and CN-A inhibited colony formation to $23 \%$ of controls (Fig. 4B).

Effects of $C N-A$ analogues on the growth of MCF-7 cells in the presence of $A T O$. We next examined whether the active $\mathrm{CN}-\mathrm{A}$ analogue and ATO also cooperatively inhibited the growth of MCF-7 cells. Although ISIR-005, a synthetic CN-Aderivative, at $6 \mu \mathrm{g} / \mathrm{ml}$ slightly inhibited the growth of MCF-7 cells ( $20 \%$ inhibition) after the 5-day treatment, combined treatment with ISIR-005 plus ATO synergistically inhibited the growth of MCF-7 cells (Fig. 5A). On the other hand, FC-J, a CN-A-related natural product, at $6 \mu \mathrm{g} / \mathrm{ml}$ scarcely inhibited the growth of $\mathrm{MCF}-7$ cells after the 5-day treatment and also could not enhance ATO-induced growth inhibition (Fig. 5B). Furthermore, similar results were obtained from ATO treatment plus 12OH-ISIR-005, an inactive analogue of ISIR-005 (Fig. 5C).

$C N-A$ and ATO synergistically increased the expression of cleaved caspase-7 in MCF-7 cells. We next examined whether the combined treatment with $\mathrm{CN}-\mathrm{A}$ and ATO inhibited growth of MCF-7 cells through the induction of apoptosis. Although

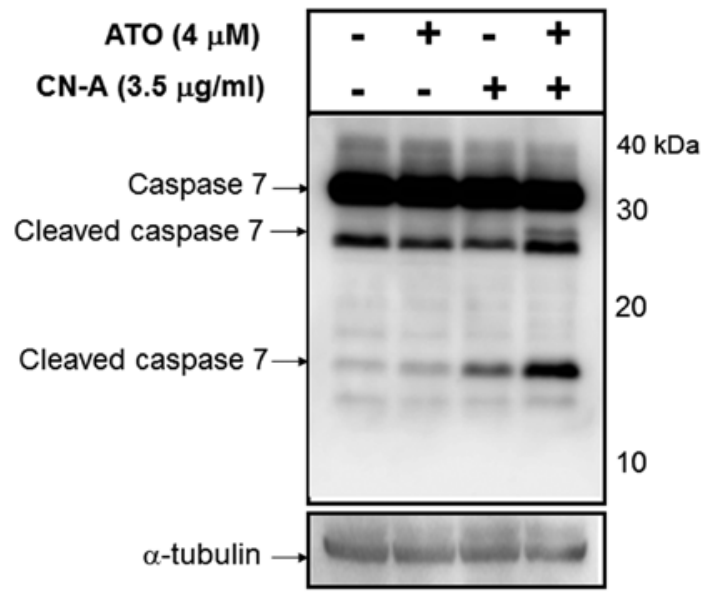

Figure 6. Detection of cleaved caspase-7 by western blot analysis. MCF-7 cells were cultured with $4 \mu \mathrm{M}$ ATO, $3.5 \mu \mathrm{g} / \mathrm{ml} \mathrm{CN}$-A or both ATO and $\mathrm{CN}-\mathrm{A}$ for $96 \mathrm{~h}$. Then whole cell lysates were obtained and used for western blot analysis. Expression of $\alpha$-tubulin protein serves as the loading control Similar results were obtained in two additional experiments.
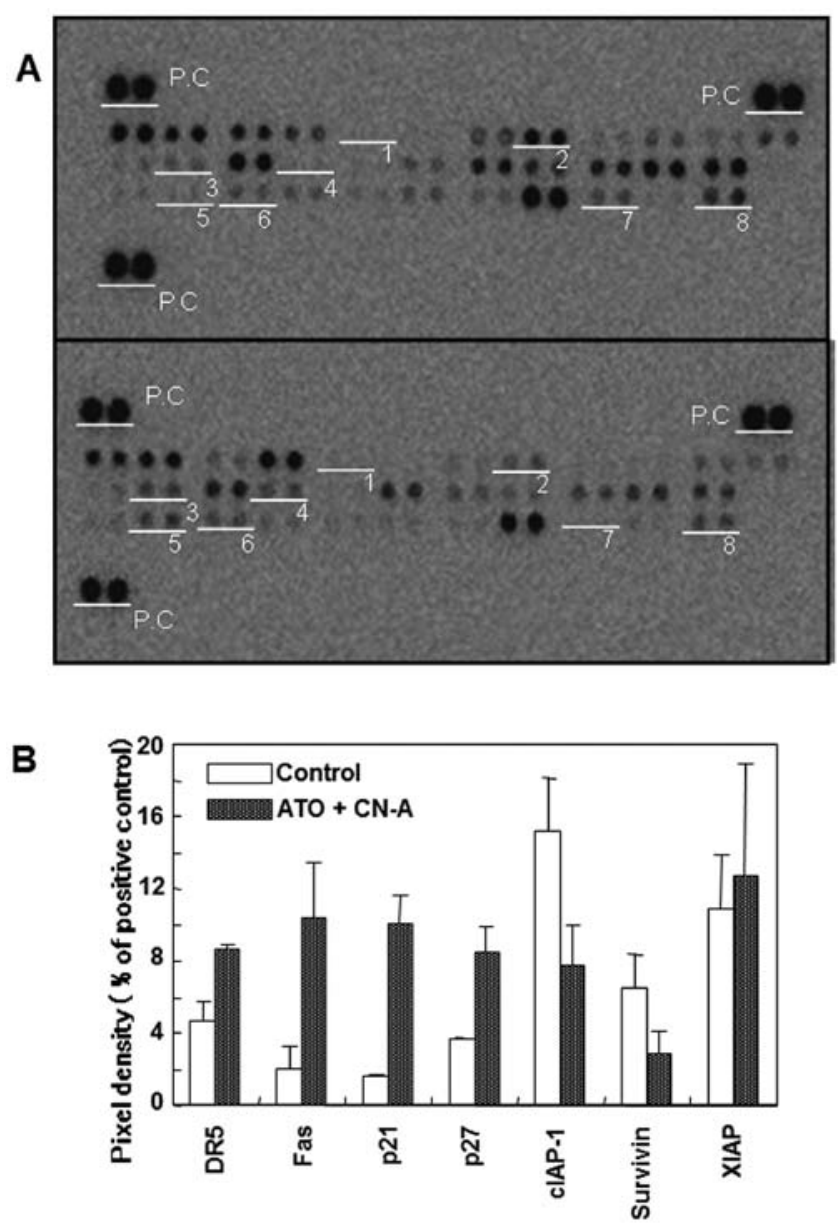

Figure 7. Effects of CN-A and ATO on the expression of apoptosis-associated proteins in MCF-7 cells. Apoptosis array analysis. (A) MCF-7 cells were cultured with $4 \mu \mathrm{M}$ ATO, $3.5 \mu \mathrm{g} / \mathrm{ml} \mathrm{CN}$-A or both ATO and CN-A for $96 \mathrm{~h}$. Whole cell lysate were used for each apoptosis array. White underline show spots for: 1, pro-caspase-3; 2, cIAP-1; 3, TRAIL R2/DR5; 4, Fas; 5, p21/CIP1; 6, p27/Kip1; 7, survivin; and 8, XIAP. P.C, positive control. The results are representative of 3 independent experiments. (B) Expression levels of these apoptosis-related proteins were quantified using an image analyzer. The expression levels are shown as percentages of positive control spots. Data represent the mean \pm standard deviation of three independent apoptosis array analyses. 

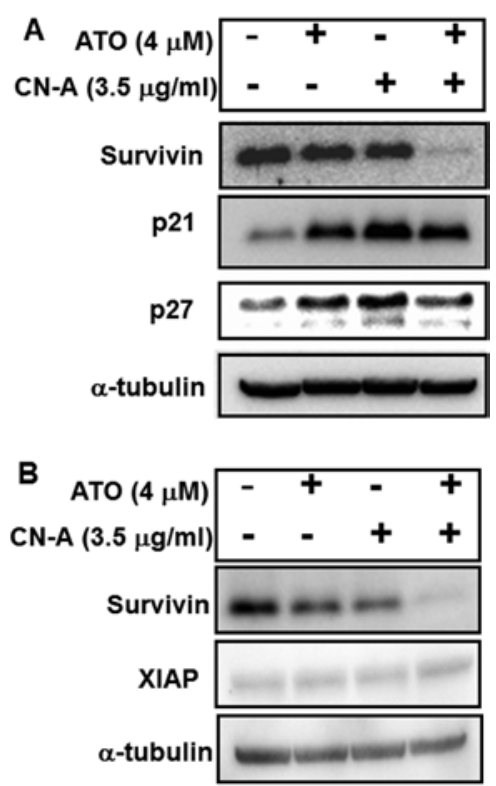

Figure 8. Western blot analyses for survivin, XIAP, p21/CIP1 and p27/Kip1 proteins. MCF-7 cells were cultured with $4 \mu \mathrm{M}$ ATO, $3.5 \mu \mathrm{g} / \mathrm{ml} \mathrm{CN}$-A or both ATO and CN-A for $96 \mathrm{~h}$. Whole cell lysate were used for western blot analysis. Expression of $\alpha$-tubulin protein serves as the loading control. Similar results were obtained in two additional experiments.

cleaved caspase-3 is used for one of the markers of apoptosis (32), MCF-7 cells lack expression of caspase-3 as a result of a 47-bp deletion in exon 3 of the CASP 3 gene (33). Since there were reports that in MCF-7 cells apoptosis was induced through the activation of caspase-7 instead of caspase-3 (34), we examined whether the combined treatment with $\mathrm{CN}-\mathrm{A}$ and ATO could induce cleaved caspase-7. MCF-7 cells were cultured with $4 \mu \mathrm{M}$ ATO, $3.5 \mu \mathrm{g} / \mathrm{ml} \mathrm{CN-A}$ or both ATO and $\mathrm{CN}-\mathrm{A}$ for $96 \mathrm{~h}$. Although ATO alone scarcely induced cleaved caspase- 7 and CN-A alone only weakly induced cleaved caspase-7, this combined treatment markedly induced cleaved caspase-7 in MCF-7 cells (Fig. 6). These results suggest that the combined treatment with $\mathrm{CN}-\mathrm{A}$ and ATO induced apoptosis through the activation of caspase- 7 .

Characterization of the combined treatment-induced apoptosis. In order to investigate further the mechanism by which both CN-A and ATO induce apoptosis, various apoptosisrelated proteins were examined using apoptosis array analysis. MCF-7 cells were cultured with $4 \mu \mathrm{M}$ ATO, $3.5 \mu \mathrm{g} / \mathrm{ml} \mathrm{CN-A}$ or both ATO and CN-A for $96 \mathrm{~h}$. Whole cell lysates were used for each apoptosis array spotted with 35 antibodies specific to apoptosis-related proteins. As mentioned above, the expression of caspase-3 was not detected in this array (Fig. 7A spot number 1). The expression of death receptors [DR5 (TRAIL receptor 2) and Fas] and inhibitors of cell cycle (p21/CIP1 and p27/Kipl) were significantly induced (Fig. 7A and B). On the other hand, among the inhibition of apoptosis (IAP) family, expressions of cIAP-1 and survivin were clearly decreased but the expression of XIAP was not significantly changed (Fig. 7A and B). We further examined expressions of survivin, XIAP, p21/CIP1 and p27/Kip1 proteins by western blot analysis (Fig. 8). We found that the expression of survivin in MCF-7 cells was dramatically decreased in the presence of both
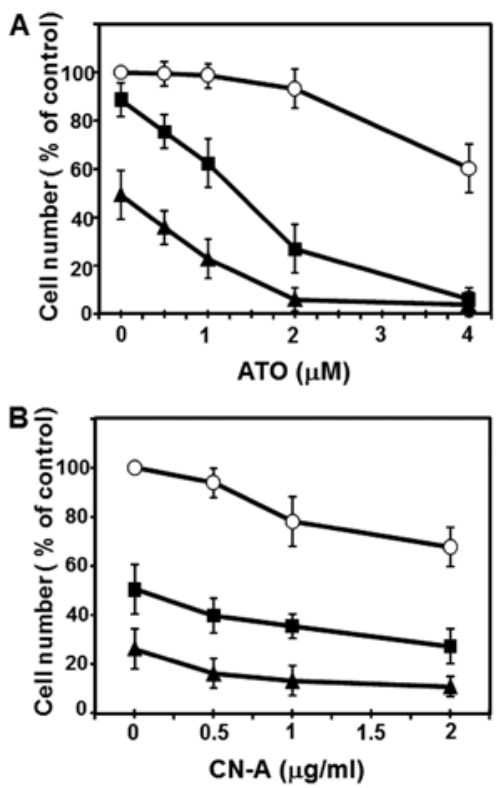

Figure 9. Effects of survivin inhibitor YM155 on the ATO-induced or CN-Ainduced growth inhibition of MCF-7 cells. (A) MCF-7 cells $\left(1 \times 10^{4}\right.$ cells $\left./ \mathrm{ml}\right)$ were cultured with ATO in the absence (open circle) or presence of $2.5 \mathrm{nM}$ (closed square) and $5 \mathrm{nM}$ (closed triangle) YM155 for 5 days. (B) MCF-7 cells $\left(1 \times 10^{4}\right.$ cells $\left./ \mathrm{ml}\right)$ were cultured with $\mathrm{CN}-\mathrm{A}$ in the absence (open circle) or presence of $5 \mathrm{nM}$ (closed square) and $10 \mathrm{nM}$ (closed triangle) YM155 for 5 days. Then cell numbers were determined by the MTT assay. Values are expressed as mean \pm standard deviation of three determinations.

$\mathrm{CN}-\mathrm{A}$ and ATO, although the expression of survivin was only slightly decreased by CN-A or ATO alone (Fig. 8A and B). On the other hand, the expression of XIAP was not significantly modulated by CN-A and/or ATO (Fig. 8B).

$\mathrm{CN}-\mathrm{A}$ or ATO alone clearly induced p21/CIP1 and p27/Kip1 proteins. The combined treatment with $\mathrm{CN}-\mathrm{A}$ and ATO did not further increase the p21/CIP1 and p27/Kip1 proteins (Fig. 8A).

Effect of YM155 (survivin inhibitor) on the CN-A-induced or ATO-induced growth inhibition of MCF-7 cells. As mentioned above, our results suggest that the induction of cleaved caspase- 7 and the inhibition of survivin are important events in the corporative inhibition of growth of MCF-7 cells by both CN-A and ATO. Since survivin is a direct inhibitor of caspasse-3 and -7 (35), we examined the effect of the survivin inhibitor YM155 (36), on the CN-A-induced or ATO-induced growth inhibition of MCF-7 cells. As shown in Fig. 9A, YM155 and ATO synergistically inhibited the growth of MCF-7 cells. Whereas ATO at $2 \mu \mathrm{M}$ or YM155 at $2.5 \mathrm{nM}$ alone scarcely inhibited the growth of MCF-7 cells, the combined treatment with ATO and YM155 inhibited growth to $<30 \%$ of control (Fig. 9A). On the other hand, the combined treatment with CN-A and YM155 showed only additive growth inhibition of MCF-7 cells (Fig. 9B). These results suggest that the synergistic growth inhibition by both $\mathrm{CN}-\mathrm{A}$ and ATO was, at least in part, due to the synergistic inhibition of survivin induced by both CN-A and ATO.

Effect of $N$-acetylcysteine (antioxidant compound) on combined treatment-induced growth inhibition of MCF-7 cells. Next, we determined whether oxidative stress was involved in 


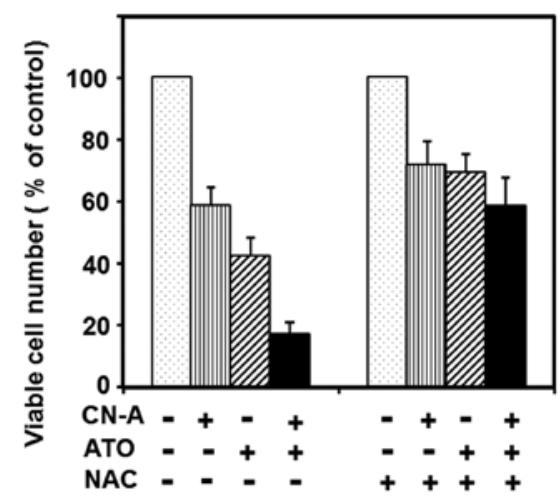

Figure 10. NAC partially rescues the growth suppression induced by the combination treatment with CN-A plus ATO. MCF-7 cells were pretreated with $10 \mathrm{mM}$ NAC, followed by $3 \mu \mathrm{g} / \mathrm{ml} \mathrm{CN}-\mathrm{A}$ and $2 \mu \mathrm{M}$ ATO for $96 \mathrm{~h}$. Then cell numbers were determined by the MTT assay. Values are expressed as mean \pm standard deviation of three determinations.

the combined treatment with $\mathrm{CN}-\mathrm{A}$ and ATO -induced growth inhibition. An antioxidant compound $\mathrm{N}$-acetylcysteine (NAC) that can broadly scavenge reactive oxygen species (ROS) was used to reduce ROS-induced cellular stress. When cell growth rate was assessed, pretreatment with NAC significantly reduced the combination treatment-induced cell growth inhibition (Fig. 10). Furthermore, we found that hydrogen peroxide at low doses could enhance the CN-A-induced or ATO-induced growth inhibition of MCF-7 cells (data not shown). These data suggest that oxidative response plays an essential role in the combination treatment-induced apoptosis.

$C N-A$ and ATO synergistically inhibit cell invasion capacity of MDA-MB-231 cells. Finally, we examined whether the combined treatment with $\mathrm{CN}-\mathrm{A}$ and ATO also could be effective in the suppression of the invasive capacity of MDA-MB-231 cells. For the detection of MDA-MB-231 cell invasion, we used the impedance-based xCELLigence Real-Time Cell Analysis (RTCA) technology. Matrigel $(5 \%, \mathrm{v} / \mathrm{v})$ as extracellular matrix component was added on the top of the microporous membranes of upper chambers. Under this condition, MDA-MB-231 cells could invade time-dependently to lower chambers, whereas MCF-7 and T47D cells could not invade (Fig. 11A). We found that CN-A alone could dose-dependently inhibit the invasion activity of MDA-MB-231 cells (Fig. 11B). As previously reported using standard Matrigel-coated Transwell assay, we confirmed that ATO alone also inhibited the invasion activity in this assay (Fig. 11C). Furthermore, we found that the combined treatment with CN-A and ATO completely suppressed the invasion activity (Fig. 11C).

\section{Discussion}

ATO is an approved treatment for APL. In addition to APL, the antitumor activity of ATO has been reported in a variety of solid tumor cell lines including breast, esophageal, cervical, lung, liver, prostate and liver carcinoma (8-13). However, it was reported that many solid tumors are less sensitive to ATO than APL. The requirement of higher doses of ATO for the induction of effective growth inhibition of solid tumor cells was associ-
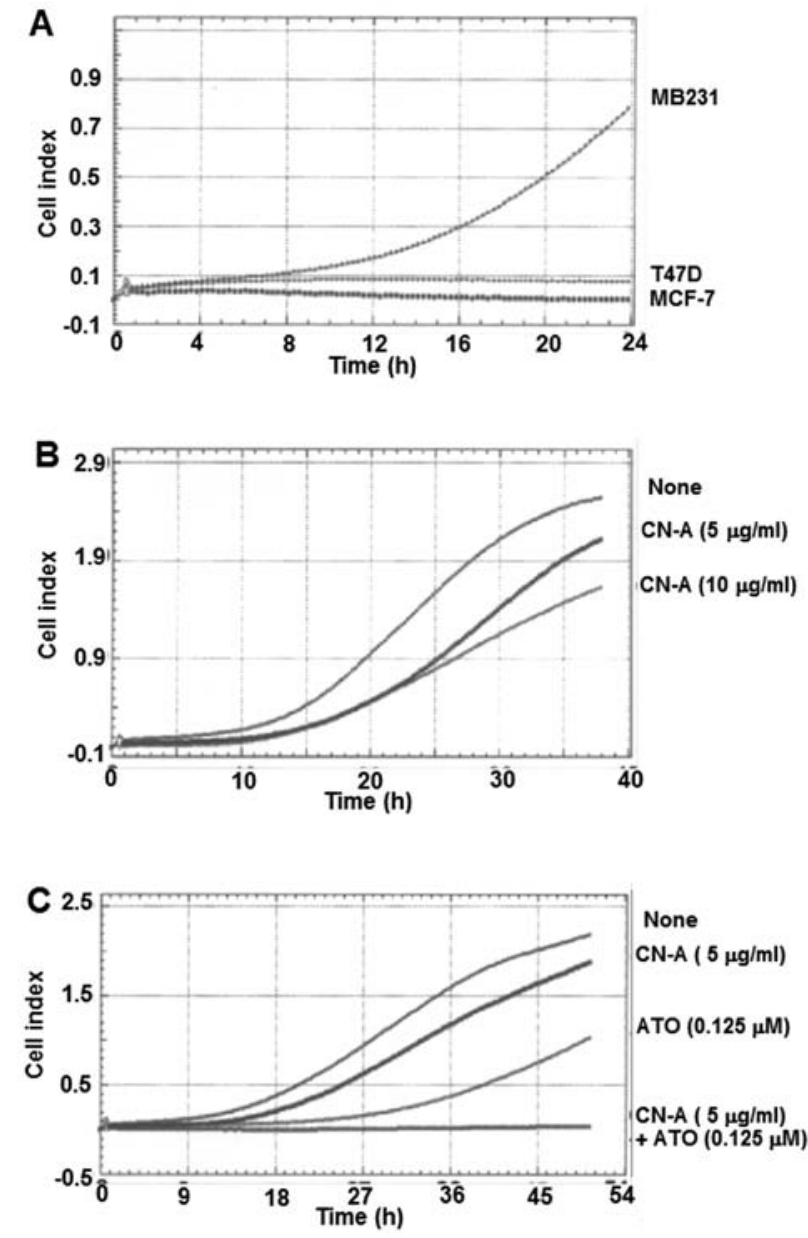

Figure 11. Time-dependent cell invasion profiles generated by $x$ CELLigence. (A) MDA-MB-231 (MB231) $\left(5 \times 10^{4}\right)$, MCF-7 or T47D cells were seeded in a $5 \%(\mathrm{v} / \mathrm{v})$ Matrigel-coated CIM-Plate 16 with $10 \%$ serum serving as the chemoattractant in the lower chamber. Similar results were obtained in two additional experiments. (B) MDA-MB-231 cells were cultured with or without $5 \mu \mathrm{g} / \mathrm{ml}$ and $10 \mu \mathrm{g} / \mathrm{ml} \mathrm{CN-A} \mathrm{for} 96 \mathrm{~h}$. Then, $5 \times 10^{4}$ MDA-MB-231 cells were seeded in a 5\% (v/v) Matrigel-coated CIM-Plate 16 with $10 \%$ serum serving as the chemoattractant in the lower chamber. Similar results were obtained in two additional experiments. (C) MDA-MB-231 cells were cultured with $5 \mu \mathrm{g} / \mathrm{ml} \mathrm{CN-A,} 0.125 \mu \mathrm{M}$ ATO or CN-A plus ATO for $96 \mathrm{~h}$. Then, $5 \times 10^{4}$ MDA-MB-231 cells were seeded in a $5 \%(\mathrm{v} / \mathrm{v})$ Matrigel-coated CIM-Plate 16 with $10 \%$ serum serving as the chemoattractant in the lower chamber. Similar results were obtained in two additional experiments.

ated with the risk of severe adverse effects such as leukopenia, anemia, fever and vomiting (14-16,37). Combination therapy is a frequently used method in clinical practice to improve the therapeutic effect and reduce the toxicity of anticancer drugs $(17,18)$. Therefore, novel strategies of treatment which can potentiate the antitumor activity and alleviate toxicity are needed for employment of ATO on patients with solid tumors. In the present study, we showed that low doses of ATO and $\mathrm{CN}-\mathrm{A}$, which is a potent differentiation inducer of myeloid leukemia cells, could inhibit cooperatively the cell proliferation of human breast cancer MCF-7 cells and MDA-MB-231 cells measured by both MTT assay and methylcellulose colony-formation assay. These results suggest that CN-A is an attractive enhancer for ATO-induced anticancer activities in human breast cancer.

Cleaved caspase- 3 is used for a marker of apoptosis induction in several types of cancer cells (32). Although MCF-7 
cells lack expression of caspase- 3 as a result of a 47-bp deletion in exon 3 of the CASP3 gene (33), there is a report that MCF-7 cells induced apoptosis through the activation of caspase-7 instead of caspase-3 (34). The combined treatment with $4 \mu \mathrm{M}$ ATO and $3.5 \mu \mathrm{g} / \mathrm{ml} \mathrm{CN-A} \mathrm{markedly} \mathrm{induced} \mathrm{cleaved} \mathrm{caspase-7}$ in MCF-7 cells, although ATO alone scarcely induced cleaved caspase-7 and $\mathrm{CN}-\mathrm{A}$ alone only weakly induced cleaved caspase-7 (Fig. 6). These results suggest that the combined treatments with $\mathrm{CN}-\mathrm{A}$ and ATO induced apoptosis through the activation of caspase-7. Accompanying with this synergistic induction of cleaved caspase-7 by the treatment with $\mathrm{CN}-\mathrm{A}$ plus ATO, we also found that the expression of survivin, which is a member of IAP family and a direct inhibitor of caspase-3 and -7 (35), significantly decreased in MCF-7 cells treated with both CN-A and ATO (Figs. 7 and 8), although the expression of survivin was only slightly decreased by $\mathrm{CN}-\mathrm{A}$ or ATO alone (Fig. 8). Furthermore, we found that ATO and the survivin inhibitor YM155 also synergistically inhibited the growth of MCF-7 cells (Fig. 9). These results suggest that the induction of cleaved caspase-7 and inhibition of survivin are important events in the corporative inhibition of growth of MCF-7 cells by both CN-A and ATO.

The pretreatment with antioxidant NAC significantly reduced the combination treatment-induced cell growth inhibition (Fig. 10). We observed that the growth of MCF-7 cells was synergistically inhibited by the treatment with both $\mathrm{CN}-\mathrm{A}$ and low doses of hydrogen peroxide (one of ROS) or the treatment with both ATO and hydrogen peroxide (data not shown). These results suggest that oxidative response plays an essential role in the combination treatment-induced apoptosis and also suggest that ROS-inducing drugs or substances could further enhance ATO-induced, CN-A-induced, or the combined treatment with $\mathrm{CN}$-A and ATO-induced growth inhibition of tumor cells. Indeed, recently Nakaoka et al (38) reported that ATO and cisplatin (a ROS inducer) showed synergistic anticancer activity in oral squamous cell carcinoma cells. On the other hand, we found that $\mathrm{CN}-\mathrm{A}$ and cisplatin showed synergistic anticancer activity in MCF-7 cells (data not shown).

In addition to inhibiting cell proliferation of cancer cells, suppression of cell invasion capacity of cancer cells is very important for development of effective cancer treatment. Therefore, we also examined the effects of CN-A, ATO or combined treatment with $\mathrm{CN}-\mathrm{A}$ and ATO on the cell invasion capacity of human breast cancer cells by using the impedancebased xCELLigence RTCA technology. We confirmed that invasion capacity was observed in MDA-MB-231 cells but not in MCF-7 and T47D cells using xCELLigence RTCA technology as previously reported (39). We found that CN-A alone could dose-dependently inhibit the invasion capacity of MDA-MB-231 cells. According to a recent report using Transwell assay (40), ATO also attenuated the invasion capacity of MDA-MB-231 cells in xCELLigence assay. Finally, we found that the combined treatment with $\mathrm{CN}-\mathrm{A}$ and ATO markedly suppressed the invasion capacity (Fig. 11). Although the combined treatment with $\mathrm{CN}-\mathrm{A}$ and ATO in these experiments did not induce apoptosis (data not shown), the mechanism of this marked suppression of the invasion capacity is still not known and further studies are needed.

In conclusion, $\mathrm{CN}-\mathrm{A}$ and ATO cooperatively suppress cell proliferation and cell invasion capacity of human breast cancer cells. These results suggest that $\mathrm{CN}-\mathrm{A}$ is an attractive enhancer for the ATO-induced anticancer activities in human breast cancer.

\section{Acknowledgements}

The present study was supported partly by a grant from the Ministry of Education, Culture, Sports, Science, and Technology of Japan.

\section{References}

1. Siegel R, Naishadham D and Jemal A: Cancer statistics, 2013. CA Cancer J Clin 63: 11-30, 2013.

2. Siegel R, Naishadham MA and Jemal A: Cancer statistics, 2012. CA Cancer J Clin 62: 10-29, 2012.

3. Hurvitz S, Hu Y, O'Brien N and Finn RS: Current approaches and future directions in the treatment of HER2-positive breast cancer. Cancer Treat Rev 39: 219-229, 2013

4. Gianni M, Koken MH, Chelbi-Alix MK, Benoit G, el al: Combined arsenic and retinoic acid treatment enhances differentiation and apoptosis in arsenic-resistant NB4 cells. Blood 91: 4300-4310, 1998

5. Shen ZX, Chen GQ, Ni XS, el al: Use of arsenic trioxide $\left(\mathrm{As}_{2} \mathrm{O}_{3}\right)$ in the treatment of acute promyelocytic leukemia (APL): II. Clinical efficacy and pharmacokinetics in relapsed patients. Blood 89: 3354-3360, 1997.

6. Deuer D and Tallman MS: Arsenic trioxide: new clinical experience with an old medication in hematologic malignancies. $\mathrm{J}$ Clin Oncol 23: 2396-2410, 2005.

7. Platanias L: Biological responses to arsenic compounds. J Biol Chem 284: 18583-18587, 2009.

8. Emadi A and Gore SD: Arsenic trioxide-An old drug rediscovered. Blood Rev 24: 191-199, 2010.

9. Takahashi S: Combination therapy with arsenic trioxide for hematological malignancies. Anticancer Agents Med Chem 10: 504-510, 2010.

10. Zhang X, Su Y and Sun Z: Opposite effects of arsenic trioxide on the Nrf2 pathway in oral squamous cell carcinoma in vitro and in vivo. Cancer Lett 18: 93-98, 2012.

11. Kryeziu K, Jungwirth U, Hoda MA, el al: Synergistic anticancer activity of arsenic trioxide with erlotinib is based on inhibition of EGFR-mediated DNA double-strand break repair. Mol Cancer Ther 12: 1073-1084, 2013.

12. Liu W, Gong Y, Li H, el al: Arsenic-induced growth arrest of breast cancer MCF-7 cells involving FOXO3a and IkB kinase $\beta$ expression and localization. Cancer Biother Radiopharm 27: 504-512, 2012.

13. Kasukabe T, Okabe-Kado J, Haranosono Y, Kato $\mathrm{N}$ and Honma Y: Inhibition of rapamycin-induced Akt phosphorylation by cotylenin A correlated with their synergistic growth inhibition of cancer cells. Int J Oncol 42: 767-775, 2013.

14. Vuky J, Yu R, Schwartz L and Motzer RJ: Phase II trial of arsenic trioxide in patients with metastatic renal cell carcinoma. Invest New Drugs 20: 327-330, 2002

15. Kim KB, Bedikian AY, Camacho LH, Papadopoulos NE and McCullough C: A phase II trial of arsenic trioxide in patients with metastatic melanoma. Cancer 104: 1687-1692, 2005.

16. Lin CC, Hsu C, Hsu CH, Hsu WL, Cheng AL and Yang CH: Arsenic trioxide in patients with hepatocellular carcinoma: a phase II trial. Invest New Drugs 25: 77-84, 2006.

17. Abe O, Abe R, Enomoto K, el al: Effects of chemotherapy and hormonal therapy for early breast cancer on recurrence and 15-year survival: an overview of the randomized trials. Lancet 365: 1687-1717, 2005.

18. Zhao XY, Yang S, Chen YR, Li PC, Dou MM and Zhang J: Resveratrol and arsenic trioxide act synergistically to kill tumor cells in vitro and in vivo. PloS One 9: e98925, 2014.

19. Sassa T, Tojyo T and Munakata K: Isolation of a new plant growth substance with cytokinin-like activity. Nature 227: 379, 1970.

20. Asahi K, Honma Y and Hazeki K: Cotylenin A, a plant-growth regulator, induces the differentiation in murine and human myeloid leukemia cells. Biochem Biophys Res Commun 238: 758-763, 1997. 
21. Yamamoto-Yamaguchi Y, Yamada K, Ishii Y, Asahi KI, Tomoyasu S and Honma Y: Induction of the monocytic differentiation of myeloid leukemia cells by cotylenin A, a plant growth regulator. Br J Haematol 112: 697-705, 2001.

22. Yamada K, Honma Y, Asahi KI, Sassa T, Hino KI and Tomoyasu S: Differentiation of human acute myeloid leukemia cells in primary culture in response to cotylenin A, a plant growth regulator. Br J Haematol 114: 814-821, 2001.

23. Honma Y: Cotylenin A: a plant growth regulator as a differentiation-inducing agent against myeloid leukemia. Leuk Lymphoma 43: 1169-1178, 2002.

24. Yamamoto-Yamaguchi Y, Okabe-Kado J, Kasukabe T and Honma Y: Induction of differentiation of human myeloid leukemia cells by immunosuppressant macrolides (rapamycin and FK506) and calcium/calmodulin-dependent kinase inhibitors. Exp Hematol 29: 582-588, 2001.

25. Kasukabe T, Okabe-Kado J, Kato N, Sassa T and Honma Y: Effects of combined treatment with rapamycin and cotylenin A, a novel differentiation-inducing agent, on human breast carcinoma MCF-7 cells and xenografts. Breast Cancer Res 7: R1097-R1110, 2005.

26. Kasukabe T, Okabe-Kado J and Honma Y: Cotylenin A, a new differentiation inducer, and rapamycin cooperatively inhibit growth of cancer cells through induction of cyclin G2. Cancer Sci 99: 1693-1698, 2008.

27. Kawakami K, Hattori M, Inoue T, et al: A novel Fusicoccin derivative preferentially targets hypoxic tumor cells and inhibits tumor growth in xenografts. Anticancer Agents Med Chem 12: 791-800, 2012

28. Nakamaki T, Okabe-Kado J, Yamamoto-Yamaguchi Y, el al: Role of MmTRA1b/phospholipid scramblase 1 gene expression in the induction of differentiation of human myeloid leukemia cells into granulocytes. Exp Hematol 30: 421-429, 2002.

29. Hagiwara Y, Kasukabe T, Kaneko Y, Niitsu N and Okabe-Kado J: Ellagic acid a natural compound, induces apoptosis and potentiates retinoic acid-induced differentiation of human leukemia HL-60 cells. Int J Hematol 92: 136-143, 2010.
30. Zhou C, Boggess J, Bae-Jump V and Gehrig PA: Induction of apoptosis and inhibition of telomerase activity by arsenic trioxide $\left(\mathrm{As}_{2} \mathrm{O}_{3}\right)$ in endometrial carcinoma cells. Gynecol Oncol 105: 218-222, 2007.

31. Kumar P, Gao Q, Ning Y, Wang Z, Krebsbach PH and Polverini PJ Mol Cancer Ther 7: 2060-2069, 2008.

32. Feng Y, Pan TC, Pant DK, el al: SPSB1 promotes breast cancer recurrence by potentiating c-MET signaling. Cancer Discov 4: 790-803, 2014

33. Janicke RU, Sprenger ML, Wati MR and Porter AG: Caspase-3 is required for DNA fragmentation and morphological changes associated with apoptosis. J Biol Chem 273: 9357-9360, 1998.

34. Aziz MY, Omar AR, Subramani T, et al: Damnacanthal is a potent inducer of apoptosis with anticancer activity by stimulating p53 and p21 genes in MCF-7 breast cancer cells. Oncol Lett 7: 1479-1484, 2014

35. Shin S, Sung BJ, Cho YS, et al: An anti-apoptotic protein human survivin is a direct inhibitor of caspase- 3 and -7 . Biochemistry 40: 1117-1123, 2001

36. Nakahara T, Takeuchi M and Kinoyama I, et al: YM155, a novel small-molecule survivin suppressant, induces regression of established human hormone-refractory prostate tumor xenografts. Cancer Res 67: 8014-8021, 2007.

37. Li W, Wang M, Wang L, Ji S, Zhang J and Zhang C: Icariin synergizes with arsenic trioxide to suppress human hepatocellular carcinoma. Cell Biochem Biophys 68: 427-436, 2014.

38. Nakaoka T, Ota A, Ono T, et al: Combined arsenic trioxidecisplatin treatment enhances apoptosis in oral squamous cell carcinoma cells. Cell Oncol 37: 119-129, 2014.

39. Limame R, Wouters A, Pauwels B, et al: Comparative analysis of dynamic cell viability, migration and invasion assessments by novel real-time technology and classic endpoint assays. PloS One 7: e46536, 2012

40. Si L, Jiang F, Li Y, et al: Induction of the mesenchymal to epithelial transition by demethylation-activated microRNA-200c is involved in the anti-migration/invasion effects of arsenic trioxide on human breast cancer cells. Mol Carcinog: Apr 14, 2014. doi: 10.1002/mc.22157. (Epub ahead of print). 